\title{
Natural Resource Endowment and Sustainable Development Linkage in Ethiopia
}

\author{
Mulugeta Bekele Eyerusalem Mebrahtom \\ Department of Economics, College of Business and Economics, Dire Dawa University, Dire. Dawa Ethiopia \\ P.O.BOX 1362 Dire Dawa, Ethiopia
}

\begin{abstract}
Natural resource endowment in many economies of the world became a curse rather than blessing. The purpose of this study is to examine the link between natural resource endowment and sustainable development in Ethiopia over the period 1981 to 2016 using an Autoregressive distributed lag (ARDL) modeling approach. The findings suggest that natural resource endowment has no significant effect on sustainable development (measured by adjusted net national income) in Ethiopia in the long run but it has a statistically significant negative effect in the short run, supporting the hypothesis in the resource curse literature. Among the other variables included in the model of sustainable development, investment (gross capital formation) and human capital are found to have a significant positive effect while debt servicing is found to affect sustainable development in Ethiopia negatively in the long run. On the other hand, population growth and trade openness are found to have a statistically significant negative effect on sustainable development in Ethiopia both in the long run and short run. Policies towards increasing the human capital stock in the country, among others, are the policy options that the government could work on so as to tackle the possible problems of natural resource curse and achieve sustainable development goals in the country.
\end{abstract}

Keywords: Natural Resources Endowment; Sustainable Development; Resource Curse; Ethiopia.

DOI: $10.7176 / \mathrm{JRDM} / 63-03$

Publication date:March $31^{\text {st }} 2020$

\section{Introduction}

There is a growing awareness of the increasingly sharp demands that human societies place on their economies and their natural environment, and of the corrosion of many social and political institutions. The sustainability movement calls for a more sophisticated and inclusive view of development and well-being that explicitly takes into account ecological health, natural resource stocks, vibrant and just communities, and democratic processes (Hackett, 2006).

In more detail, Kahn (1995) clearly shows the three imperatives of sustainable development: economic sustainability, social sustainability and environmental sustainability. Economic sustainability, can be observed from point of view of, growth, productivity and trickle down whereas, social sustainability, can be observed from point of view of, equity, empowerment, accessibility, participation, sharing, institutional stability and environmental sustainability, can be observed from point of view of, eco-system integrity, carrying capacity and biodiversity. Therefore, the extraction and consumption of resources should be in line with these objectives.

Ethiopia's economy experienced strong, broad-based growth averaging 10.3 percent a year from 2006/07 to 2016/17. Agriculture, construction and services accounted for most of the growth, with modest contribution from the manufacturing sector. The top ten exports of the country mostly comprises of primary commodities. Although the country has geological potential for the discovery of new, sizeable oil, gas and mineral deposits, most of its extractive industries are infant. Currently, there is one large scale gold mine in operation, 'Lege Dembi open pit mine', while a growing number of large mining projects are under development and exploitations for oil and natural gas is intensifying after significant discoveries in neighboring countries (WBG, 2018).

The question is what kind of relationship do exists between natural resources endowment and sustainable development? Can resource endowment matters for sustainable development? Mahatma Gandhi, rightly pointed out that, "The earth provides enough to satisfy everyone's need, but not everyone's greed" (Singh, 2006).

Earliest growth theories indicates that significant revenues from natural resources should generate wealth, improves economic growth and reduces poverty. However, existing studies end up with mixed results, viewing natural resources as both a curse and blessing. In particular, after Sachs and Warner $(1995,1997,2001)$, assert that resource rich countries grow slower while Ross(2001,2004), states that oil hinder democracy and fuels civil wars, the resource curse given too much attention. There are, however, a few countries that have managed to avoid this paradox which referred as exceptions of resource curse (Gylfason, 2010).

In the resource led-growth literature natural resource endowment leads to development. Conceptual frameworks such as the staples theory and the vent for surplus theory consider the presence of excess resources that are insufficiently exploited in economies usually small and closed and trade allows to foster exports and growth because natural resources are used productively (Barbier, 2007), mining promoted the establishment of prestigious educational centers and diffused knowledge to other activities (David et al., 1997; Wright, 2001). 
However, in the resource curse literature natural resource endowment leads to underdevelopment. The allocation of resources between productive sectors with different spillover effects on aggregate growth emphasizes the role of specialization in economic development. Economies in which production is based on natural resource abundance, where manufacturing and services account for only a small share of the productive structure, will grow more slowly (Philip, 2007; Jalloh, 2013 and Nezhad, 2014), in addition, the so-called Dutch disease is an important concept in the literature on the natural resource curse hypothesis. Economies with abundant natural resources are subject to periodic rises and falls in their performance because commodity prices on world markets are variable and from time to time new exploitable natural resources are discovered. This process generates volatility in export and fiscal earnings and a real appreciation in the value of the country's currency, hurting other export industries (Willebald et.al, 2015).

Further, in a society with rampant corruption, more natural resources may hinder growth. In such countries more natural resources may stimulate predation, rent-seeking, and other destructive and/or non-productive activities, in turn creating negative externalities for the rest of the economy (Torvik, 2009), institutional quality can help reduce the curse or may even turn it into a blessing, but it is not obvious what type of institutional qualities is most beneficial in reaping the benefits of natural resources (Moshiri, 2017).

Why this study? prior works that examines the link between natural resource endowment and economic growth or development, didn't purely consider the issue of sustainable development, as far as the concept and measures of economic growth and economic development are different from sustainable development this consideration is vital. Furthermore, as far as our literature covers no previous empirical works exist in Ethiopia on this area. Therefore, this study tries to fill this gap.

There are wide range of ambitious development visions in Ethiopia, in order to achieve those goals a systematic examination of the link between natural resource endowment and sustainable development is crucial. Specifically, the study seeks; (1) To identify whether there is any co-integrating relationship between natural resource endowment and sustainable development in Ethiopia; and (2) To investigate empirically the short run and long run relationship between natural resource endowment and sustainable development in Ethiopia.

\section{Methodology}

\subsection{Theoretical Framework}

In specifying the model of sustainable development to be estimated, the theoretical framework for this study closely follows the specification given in Ding et al. (2016). Following the resource curse literature, the empirical specification in Ding et al. (2016) captures the effects of natural resource endowment on development based on a variant of endogenous growth model specified as:

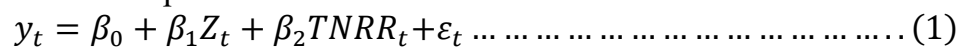

where $y t$ represents adjusted net national income, $Z$ denotes a vector of control variables for sustainable development, (TNRR) represents total natural resources rents (\% of GDP) which is a proxy for natural resource endowment, and $\varepsilon$ is the error term that is assumed to be white noise.

\subsection{The Econometric Approach}

\subsubsection{The Empirical Model in ARDL Framework}

In the literature, a number of co-integration approaches such as the Engle-Granger (1987), Johansen (1988), and Pesaran et al (2001) ARDL approach, among others, are used. This study employs ARDL bounds testing approach to co integration advanced by Pesaran et al. (2001). The Pesaran et al (2001) ARDL approach has a number of advantages over other traditional co integration approaches (Yimer, 2017). Specially, it is comparatively more robust and efficient in small and finite samples consisting of 30 to 80 observations (Pesaran et al., 2001). The above advantages of the ARDL technique over other standard co-integration techniques justify the application of ARDL approach in the present study. The methodological procedure in the ARDL framework involves first, it requires the checking of none of the variables have an integration order of 2 or higher. In order to do that, the augmented Dickey-Fuller (ADF) test for checking the order of integration among the series is used. At the second step, the ARDL bounds testing approach to co integration developed by Pesaran et al. (2001) is applied. In order to do the bound test, the ARDL model used in this study is specified as

$$
\begin{array}{r}
\Delta y_{t}=\alpha_{0}+\beta_{1} y_{t-1}+\beta_{2} P G R_{t-1}+\beta_{3} I_{t-1}+\beta_{4} H C I_{t-1}+\beta_{5} O P_{t-1}+\beta_{6} D S R_{t-1}+\beta_{7} T N R R_{t-1}+ \\
\sum_{i=1}^{p} \delta_{1} \Delta y_{t-i}+\sum_{i=1}^{p} \delta_{2} \Delta P G R_{t-i}+\sum_{i=1}^{p} \delta_{3} \Delta I_{t-i}+\sum_{i=1}^{p} \delta_{4} \Delta H C I_{t-i}+\sum_{i=1}^{p} \delta_{5} \Delta O P_{t-i}+\sum_{i=1}^{p} \delta_{6} \Delta D S R_{t-i}+ \\
\sum_{i=1}^{p} \delta_{7} \Delta T N R R_{t-i}+\varepsilon_{t} \ldots \text { (2) }
\end{array}
$$

Where, $y_{t}$ represents adjusted net national income which is a measure of sustainable development, PGR is population growth rate, I is investment, HCI is human capital index, OP is trade liberalization, DSR is debt servicing ratio, TNRR is total natural resource rent, $\alpha_{0}$ is the deterministic drift parameter and $\Delta$ denotes the first difference of the respective variables. $\varepsilon_{t}$ is the white noise error term. $p$ is the maximum lag length which is determined by the user.

In order to test co-integration among the variables, Pesaran et al. (2001) suggests the F-test for joint 
significance of the coefficients of the lagged level of variables in Eq (2). The F-statistics for testing the joint null hypotheses $\left(H_{0}\right)$ has to be compared with the critical values as tabulated by Pesaran et al. (2001). The $H_{0}$ to be tested on equation (2) is

$$
H_{0}: \beta_{1}=\beta_{2}=\beta_{3}=\beta_{4}=\beta_{5}=\beta_{6}=\beta_{7}=\beta_{8}=\beta_{9}=\beta_{10}=\beta_{11}=\beta_{12}=\beta_{13}=0 \ldots
$$

The alternative hypothesis against the null is given as

$$
H_{1}: \beta_{i} \neq 0
$$

If $H_{0}$ hypothesis can be rejected then co-integration can be confirmed. Pesaranet al. (2001) provided two sets of critical values - lower and upper bound critical - for a given level of significance. Therefore, decision was made based on those values.

If the null hypothesis of no co integration is rejected, following the procedure in Pesaranet al. (2001), the error-correction model (ECM) will be estimated in the second step. The ECM is specified as follows:

$$
\begin{gathered}
\Delta y_{t}=\alpha_{0}+\theta e c_{t-1}+\sum_{i=1}^{p} \delta_{1} \Delta y_{t-i}+\sum_{i=1}^{p} \delta_{2} \Delta P G R_{t-i}+\sum_{i=1}^{p} \delta_{3} \Delta I_{t-1}+\sum_{i=1}^{p} \delta_{4} \Delta H C I_{t-i}+\sum_{i=1}^{p} \delta_{5} \Delta O P_{t-i} \\
+\sum_{i=1}^{p} \delta_{6} \Delta D S R_{t-i}+\sum_{i=1}^{p} \delta_{7} \Delta T N R R_{t-i}+v_{t} \ldots \text { (5) }
\end{gathered}
$$

Where, $\delta_{1}, \delta_{2}, \delta_{3}, \delta_{4}, \delta_{5}, \delta_{6}, \delta_{7}$ are the short-run dynamic coefficients of the model's convergence to equilibrium, $\theta$ is the speed of adjustment from the short-run to the long-run equilibrium among the variables, and $e c_{t-1}$ is the error-correction term.

\subsection{Description of Variables and Source of Data \\ Dependant Variable}

Sustainable development: According to Hanley et al. (2007) the best measure of sustainable economic development is green net national product or adjusted net national income which takes in to account consumption of fixed capital and natural resources depletion. In this study the proxy of sustainable development is adjusted net national income measured by GNI minus consumption of fixed capital and natural resources depletion. This data

\begin{tabular}{|c|c|c|c|}
\hline Variables & Measurement & $\begin{array}{l}\text { Expected } \\
\text { sign }\end{array}$ & Source of data \\
\hline $\begin{array}{l}\text { Total Natural } \\
\text { Resource Rents \% of } \\
\text { GDP (TNRR) }\end{array}$ & $\begin{array}{l}\text { Sum of oil rents, natural gas rents, coal rents } \\
\text { (hard and soft), mineral rents, and forest rents }\end{array}$ & $?$ & World Bank \\
\hline $\begin{array}{l}\text { Population Growth } \\
\text { Rate (PGR) }\end{array}$ & $\begin{array}{l}\text { Annual population growth rate for year } t \text { is } \\
\text { the exponential rate of growth of midyear } \\
\text { population from year } t-1 \text { to } t \text {, expressed as a } \\
\text { percentage }\end{array}$ & Negative & World Bank \\
\hline Investment (I) & $\begin{array}{l}\text { Total investment measured in millions of birr } \\
\text { represents gross capital formation }\end{array}$ & Positive & $\begin{array}{l}\text { National Bank of } \\
\text { Ethiopia }\end{array}$ \\
\hline $\begin{array}{l}\text { Human Capital Index } \\
\text { (HCI) }\end{array}$ & $\begin{array}{c}\text { Based on years of schooling and returns to } \\
\text { education }\end{array}$ & Positive & $\begin{array}{l}\text { Penn world } \\
\text { table/pwt9 }\end{array}$ \\
\hline Trade Openness (OP) & $\begin{array}{l}\text { Ratio of the sum of exports and imports to } \\
\text { GDP ratio. }\end{array}$ & Negative & $\begin{array}{l}\text { United Nations } \\
\text { Conference on } \\
\text { Trade and } \\
\text { Development }\end{array}$ \\
\hline $\begin{array}{l}\text { Total debt service (\% } \\
\text { of exports of goods, } \\
\text { services and primary } \\
\text { income) (DSR) }\end{array}$ & $\begin{array}{c}\text { Sum of principal repayments and interest } \\
\text { actually paid in currency, goods, or services } \\
\text { on long-term debt, interest paid on short-term } \\
\text { debt, and repayments (repurchases and } \\
\text { charges) to the IMF. }\end{array}$ & Negative & World Bank \\
\hline
\end{tabular}
is extracted from world bank data base.

\section{Explanatory Variables}

Table 1: Summery of explanatory variables included in the study

Note: Explanatory variables are selected based on theory and empirical studies

\section{Results and Discussion}

\subsection{Introduction}

In this chapter, the studies analyzed the collected data using STATA 14 software and present the result and discussions accordingly. All the data series that are obtained are transformed into logarithms to tackle possible heteroscedasticity and autocorrelation problems. 


\subsection{Pre-estimation tests}

\subsubsection{Test for Unit Root}

Even though, the bounds test approach to co-integration does not need pre-testing for stationary of the variables included in the model, but still it is important to carry out stationary tests on all the series. This is because the ARDL bounds test to co-integration is not applicable if the order of integration is above I(1). It was therefore, necessary to test for stationary of the variables before regression analysis was done. It is notable that stationary properties of time series are investigated by testing for unit roots and there are several methods for testing for stationary. Thus, this study used the commonly used Augmented Dickey Fuller (ADF) (1981) unit root tests. The unit root tests results are presented in Table below.

Table 2: Augmented Dickey-Fuller test statistic (ADF Test)

\begin{tabular}{ccccccccc}
\hline & \multicolumn{2}{c}{ At level } & \multicolumn{2}{c}{ At first differences } & \multicolumn{3}{c}{ Critical Values } \\
\cline { 2 - 8 } Variables & $\begin{array}{c}\text { with } \\
\text { trend }\end{array}$ & $\begin{array}{c}\text { Without } \\
\text { trend }\end{array}$ & With trend & $\begin{array}{c}\text { Without } \\
\text { trend }\end{array}$ & $1 \%$ & $5 \%$ & $10 \%$ & Remark \\
LANNI & & & $-4.054 * * *$ & $-3.740 * * *$ & -3.689 & -2.975 & -2.619 & $\mathrm{I}(1)$ \\
LTNRR & & & $-6.879 * * *$ & $-6.969 * * *$ & -3.689 & -2.975 & -2.619 & $\mathrm{I}(1)$ \\
LPGR & & & $-5.515 * * *$ & $-6.703 * * *$ & -3.689 & -2.975 & -2.619 & $\mathrm{I}(1)$ \\
LHC & & $-3.575 * *$ & $-3.006 * *$ & -3.689 & -2.975 & -2.619 & $\mathrm{I}(1)$ \\
LDTSR & & & $-6.335 * * *$ & $-6.421 * * *$ & -3.689 & -2.975 & -2.619 & $\mathrm{I}(1)$ \\
LIT & & $-5.465 * * *$ & $-5.555^{* * *}$ & -3.689 & -2.975 & -2.619 & $\mathrm{I}(1)$ \\
LOP & & & $-6.199 * * *$ & $-6.280^{* * *}$ & -3.689 & -2.975 & -2.619 & $\mathrm{I}(1)$ \\
\hline
\end{tabular}

Note: $* * *, * *$ denotes stationarity at 1 percent and 5 percent level of significance respectively.

The above table shows unit root results of the series at level and first differences. The results ADF test suggest that all variables considered in the study are integrated of order one, I(1).

\subsection{Co-integrating Results}

In order to evaluate the ARDL bounds it is necessary to test for the existence of long-run relationship among the variables. The model was estimated by ARDL and the optimal lag was selected by Akaike Information criterion (AIC). After estimation we conducted an F-test on joint significance of the variables using ADRL bound Test the F-stat indicate there is a long run relationship at 1 percent, 2.5 percent, 5 percent and 10 percent between variables included in the model of sustainable development.

Table 3: ARDL Bounds test

\begin{tabular}{|c|c|c|}
\hline \multicolumn{3}{|c|}{ ARDL Bounds Test } \\
\hline \multicolumn{3}{|c|}{ Sample (adjusted): 19832016} \\
\hline \multicolumn{2}{|c|}{ Null Hypothesis: No long-run relationships exist } \\
\hline Test Statistic & Value & K \\
\hline F-statistic & 5.0497 & 6 \\
\hline Critical Value Bounds & I0 Bound & I1 Bound \\
\hline Significance & 2.03 & 3.13 \\
\hline 10 percent & 2.32 & 3.84 \\
\hline 5 percent & 2.6 & 4.26 \\
\hline 2.5 percent & 2.96 & \\
\hline 1 percent &
\end{tabular}

Note: The F-statistic tests the null hypothesis of no co integration.

\subsection{The Long Run and Short Run Model}

ARDL co integration technique proposed by (Pesaran, 2001) is the most appropriate method for estimation or to check the long run relationship among the variables. 
Table 4: Estimated Results of Sustainable Development in ARDL Model

ARDL Co integrating And Long Run Form

Dependent Variable: $\Delta(\log$ of Adjusted Net National Income)

Selected Model: ARDL(1, 2, 2 1, 1, 2, 0)

Sample (adjusted) : 1983 to 2016

\begin{tabular}{|c|c|c|c|}
\hline \multicolumn{4}{|c|}{ Short Run Coefficients } \\
\hline Variable & Coefficient & t-Statistic & Prob. \\
\hline$\Delta(\log$ of Total Natural Resource Rent) & $-0.430 * * *$ & -3.89 & 0.001 \\
\hline$\Delta(\log$ of Population Growth Rate) & $-4.185 * *$ & -2.36 & 0.030 \\
\hline$\Delta(\log$ of Debt Servicing Ratio) & -0.075 & -1.38 & 0.184 \\
\hline$\Delta(\log$ of Investment $)$ & 0.077 & 1.89 & 0.074 \\
\hline$\Delta(\log$ of Openness $)$ & $-1.242 * * *$ & -4.77 & 0.000 \\
\hline Error-correction Term & $-0.423 * * *$ & -4.664 & 0.000 \\
\hline \multicolumn{4}{|c|}{ Long Run Coefficients } \\
\hline Variable & Coefficient & t-Statistic & Prob. \\
\hline log of Total Natural Resource Rent & -0.277 & -1.19 & 0.250 \\
\hline log of Population Growth Rate & $-5.016 * * *$ & -3.04 & 0.007 \\
\hline log of Debt Servicing Ratio & $-0.245^{* *}$ & -2.37 & 0.029 \\
\hline log of Investment & $0.304 * *$ & 2.75 & 0.013 \\
\hline $\log$ of Openness & $-3.179 * * *$ & -4.61 & 0.000 \\
\hline log of Human Capital & $6.419 * * *$ & 3.19 & 0.005 \\
\hline Constant & $-10.070 * * *$ & -2.76 & 0.013 \\
\hline
\end{tabular}

Note: $* * *, * *$ and $*$ indicates 1 percent, 5 percent and 10 percent level of significance respectively

Almost all variables included in the model has the expected sign in line with theory.

The empirical ARDL model in our study shows that natural resource endowment measured by total natural resource rent as percentage of GDP has a negative impact on sustainable development of Ethiopia in the short run supporting the hypothesis in the resource curse literature, holding other things constant increase in total natural resource rent by 1 percent decreases adjusted net national income by 0.430 percent in the short run and highly statically significant at 1 percent level of significance. Our findings are consistent with previous empirical works (Philip, 2007; Hussain et al., 2009; Jalloh, 2013; Godfrey et al., 2016 ) among others that justifies the cause of resource curse are inefficient control of the government on the economy and mismanagement of natural resource rents through rent seeking, high rate of corruption in the public sector and frequent civil conflicts. However, in the long run a negative but statistically insignificant relationship observed, this may be due to the possibility to rule out the impact of natural resource dependence on sustainable development in the long run.

Among other explanatory variables included in the model of sustainable development, holding other things constant increase in 1 percent of investment measured as gross capital formation increases adjusted net national income by 0.304 percent in the long run and 0.077 in the short run and statistically significant at 5 percent and 10 percent respectively. This indicates a positive short run and long run relationship between investment (gross capital formation) and sustainable development in Ethiopia.

More importantly, an increase in human capital by 1 percent increases adjusted net national income by 6.419 percent in the long run and highly statistically significant at 1 percent level of significance. Therefore, improvement in human capital has a positive and significant impact on sustainable development of Ethiopia in the long run. This may be due to the fact that human capital enables further innovation in all sectors of the economy and leads to increasing returns.

An increase in population growth rate by 1 percent decreases adjusted net national income by 5.016 percent in the long run and 4.185 percent in the short run and statistically significant at 1 percent and 5 percent respectively. Population growth rate adversely affects sustainable development of Ethiopia both in the long run and short run and the negative impact is highly significant in the long run.

An increase in debt servicing ratio by 1 percent decreases adjusted net national income by 0.245 percent in the long run and statistically significant at 5 percent level of significance but not significant in the short run. This indicates a negative relationship between debt servicing ratio and sustainable development in Ethiopia in the long run.

An increase in trade openness by 1 percent decreases adjusted net national income by 3.179 percent in the long run and 1.242 percent in the short run and highly statistically significant at 1 percent level of significance both in the short run and long run. Trade openness negatively affects sustainable development in Ethiopia both in the short run and long run. This may be due to the fact that the gains from trade for natural resource exporting countries is insignificant due to deterioration of their terms of trade.

The ECT is statistically significant at 1 percent and negative $(-0.423)$ as expected showing that the deviation of adjusted net national income from equilibrium values is corrected by 42.3 percent in the following year. 


\subsection{Diagnostic and Model Stability Tests}

The estimated model has a good fit as can be seen from R-squared and adjusted R-squared. R-squared is the square of the correlation coefficient between the values of the dependent variable and the corresponding fitted values from the model.

Table 5: Model Diagnostic Tests

\begin{tabular}{ccc}
\hline Problems & Applicable Tests & Probabilities \\
\hline Goodness of fit & R-squared & 0.853 \\
& Adjusted R-squared & 0.733 \\
Serial correlation & Breusch-Godfrey Serial Correlation LM Test & 0.260 \\
Functional form & Ramsey RESET Test & 0.180 \\
Normality & Skewness and Kurtosis of residuals & 0.162 \\
Heteroscedasticity & White's test & 0.258 \\
\hline
\end{tabular}

Note: The null hypothesis for Skewness and Kurtosis test is that errors are multivariate normal. The null hypothesis for Breusch-Godfrey Serial Correlation LM test is that there is no problem of serial correlation. The null hypothesis for White's heteroscedasticity test is that there is no problem of heteroscedasticity. The null hypothesis for Ramsey RESET test is that the model is correctly specified. Thus such tests indicate the acceptance of the null as their respective value is greater than 10 percent level of significance. Thus there is no problem of non-normality, autocorrelation, and heteroscedasticity in the errors. In addition, the model is correctly specified.

\subsubsection{Test of Model Stability}

The stability of long run estimates has been tested by applying the cumulative sum of recursive residuals (CUSUM) such tests are recommended by Pesaran (2001). CUSUM test indicate the model is significant at 5 percent critical value.

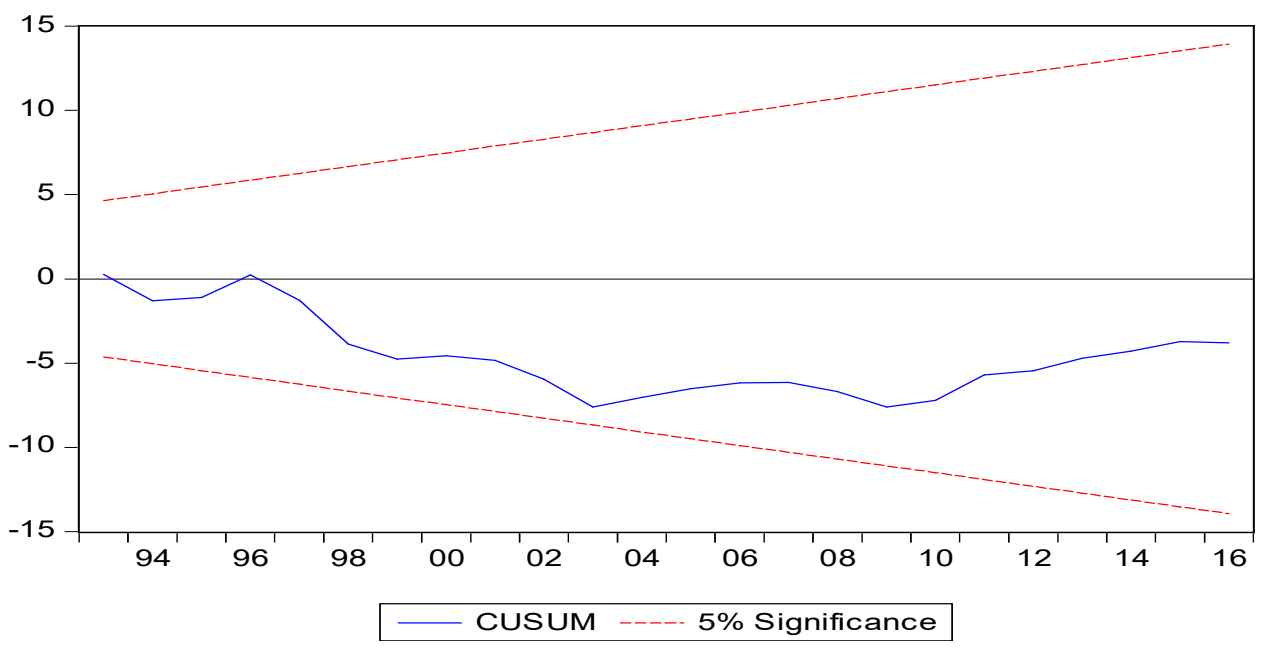

Figure 1: Parameter Stability Test

\section{Conclusion and Policy Recommendation}

\subsection{Conclusion}

This paper investigates the empirical relationship between natural resource endowment and sustainable development in Ethiopia during the period 1981-2016 by examining the long-run and short-run relationship between natural resource endowment and sustainable development in Ethiopia. The study used the Autoregressive distributed lag (ARDL) bounds testing procedure to examine the presence of long-run and short-run relationship among the variables and to investigate the association between natural resource endowment and sustainable development.

The relationship between natural resources and economic growth can be expected to be complicated and controversial. Our results are not different from previous work done by different authors on this subject. The results of the study show that there is a significant negative short-run relationship between natural resource endowment and sustainable development in Ethiopia during the sample period which supports the hypothesis in the resource curse literature, however, there is no significant relationship in the long run. Moreover, previous empirical findings also support our results that the countries that are relatively abundant in natural resources unsuccessfully performed to sustain their development paths. Robustness of estimates has been checked for reliability of results. Among the other variables included in the model of sustainable development, investment (gross capital formation) and human capital are found to have a significant positive effect while debt servicing is found to affect sustainable development in Ethiopia negatively in the long run. On the other hand, population growth and trade openness are found to have a statistically significant negative effect on sustainable development in Ethiopia both in the long run 
and short run.

\subsection{Policy Recommendations}

The findings of this study are hopefully important to design effective and critical policies in the resource sector. Based on the empirical analysis it is observed that in the short run natural resource endowment has a negative link with sustainable development implying the existence of resource curse in Ethiopia. Based on this finding we recommend that:-

4 Policies towards increasing the human capital stock in the country is the best policy options that the government could work on so as to tackle the possible problems of natural resource curse and achieve sustainable development goals in the country.

* There is a need to establish an independent institutions in the natural recourse sector that are free from government authorities influence so as to improve the management of natural resources.

* The government better improve the way and method of collecting natural resource rents and rents from natural resources should be directed in to more productive investments to achieve sustainable development goals but rather than concentrating on the natural resource rents it is better to diversify the economy by improving other sectors.

* Strengthening of the gross capital formation (investment) process is highly vital to achieve long run sustainable development goals of Ethiopia.

* The study finally calls for interested researches on the resource curse to further strength or disprove the case in Ethiopia. Since we have used total natural resources rents ( $\%$ of GDP) as a proxy for resource endowment, it would be possible for other researchers to employ other proxies such as agricultural commodity export as a percentage of GDP.

\section{REFERENCES}

1. Akanni, O. P. (2007). Oil Wealth and Economic Growth in Oil Exporting African Countries, A, September. Nairobi: AERC Research Paper .

2. Alpha, B. B., \& Ding, Y. (2016). Impact of Natural Resources Endowment on Economic Growth: Empirical Evidence from Mali. Journal of Economics and Development Studies, IV(4), 81-103.

3. Altman, M. (2003, November). Staple Theory And Export-Led Growth: Constructing Differential Growth. Australian Economic History Review, ISSN 0004-8992(3).

4. Bagheri, N. N. (2014, August). The Effect of Natural Resource Abundance on Economic Growth: A Case Study of Iran and Natural Resource Curse . University of Ottawa, Department of Economics .

5. Bah, C. M. (2016, May). Economic Growth, Institutions, and the Natural Resource Curse in Sierra Leone: an Empirical Investigation. International Journal of Business and Social Science, VII(3).

6. Barbier, E. B. (2007). The role of natural resources in economic development. WY 82071-3985, USA: University of Wyoming, .

7. Bruntland, G. (1987 ). Our Common Future: The World Commission on Environment and Development. . Oxford: Oxford University Press.

8. Chambers, E.J. and D.F. Gordon. 1966. Primary Products and Economic Growth: An Empirical Measurement. Journal of Political Economy 74(4): 315-332.

9. Chigeto, A. D. (2017). External Debt-Economic Growth Nexus in Developing Countries: Evidence from Ethiopia. International Journal of African and Asian Studies, XXXX. Retrieved from www.iiste.org

10. David, P. A., \& Wright, G. (1997). Increasing Returns and the Genesis of American Resource Abundance. Industrial and Corporate Change(6), 203-45.

11. Demissie, M. Z. (2014). The Natural Resource Curse in Sub-Saharan Africa: Transparency and International Initiatives. Dissertations. Paper 6.

12. Di Tella, G. 1982. The Economics of the Frontier. In C.P. Kindleberger and G. di Tella, eds. Economics in the Long View. Macmillan, London, pp. 210-227.

13. Ding, N., \& Field, B. C. (2004). Natural Resource Abundance and Economic Growth. Working Paper No., University of Massachusetts, Department of Resource Economics, Amherst.

14. Engle, R., \& Granger, W. (1987). Co-integration and Error Correction: Representation, Estimation and testing. Econometrica(55), 251-276.

15. Findlay, R. 1995. Factor Proportions, Trade, and Growth. MIT Press, Cambridge, Mass.

16. Gelb, A.H. (1988). Growth and Efficiency: Policy Planning and Research. Working Paper, No. 202, World Bank, Washington DC-USA.

17. Gylfason, T. (2010). Natural Resource Endowment: A Mixed Blessing?, , 3,. Macroeconomic Dynamics(3), 204-25.

18. Gylfason, T., \& Zoega, G. (2002). Inequality and Economic Growth: Do Natural Resources Matter?

19. Hackett, S. C. (2009). Environmental and Natural Resources Economics. Armonk, New York: Theory Policy, 
and the Sustainable Society Business Park Drive.

20. Humphreys, M. (2005). Natural Resources, Conflict, and Conflict Resolution: Uncovering the Mechanisms. Journal of Conflict Resolution, Vol. 49, No.2 pp.508-537.

21. Hanley, N., Shogren, F.J., \& White, B. (2007). Environmental Economics in Theory and Practice. Macmillan Ltd.

22. Hansen, B. 1979. Colonial Economic Development with Unlimited Supply of Land: A Ricardian Case. Economic Development and Cultural Change 27:611-627.

23. Hussain, S., Chaudhry, I. S., \& Malik, S. (2009). Natural Resource Abundance and Economic Growth in Pakistan. European Journal of Economics, Finance and Administrative Sciences(15).

24. Jalloh, M. (2013). Natural resources endowment and economic growth: The West African Experience. Journal of Natural Resources and Developmen, III, 66-84.

25. Johansen, S. (1988). Statistical analysis of Co integration Vectors. . Journal of Economic Dynamics and Control(12), 231-254.

26. Johansen, S. (1995). Likelihood-based Inference in Cointegrated Vector Autoregressive models. Oxford: Oxford University Press.

27. Johansen, S., \& Juselius, K. (1990). Maximum Likelihood Estimation and inference on Cointegration with applications to the Demand for money. Oxford Bulletin of Economics andStatistics(52), 169-210.

28. Kassu, T., Mishra, D., \& Asfaw, M. (2014). Public External Debt, Capital formation and Economic growth in Ethiopia. Journal of Economics and Sustainable Development, V(15). Retrieved from www.iiste.org.

29. Khan. (1995). Sustainable development_The key concepts, issues and implications. Keynote paper given at the international sustainable development research conference. Manchester.

30. Malefane, M. R., \& Odhiambo, N. M. (2018). Impact Of Trade Openness On Economic Growth: Empirical Evidence From South Africa. Working Paper, UNISA Economic Research Working Paper Series.

31. Moshiri, S., \& Hayati, S. (2017). Natural Resources, Institutions Quality, and Economic Growth; A CrossCountry Analysis, Iran. Economic Review, XXI(3), 661-693.

32. Myint, H. 1958. The Classical Theory of International Trade and the Underdeveloped Countries. Economic Journal 68:315-337.

33. Njimanted, Forgha, G., Wujung, V. A., \& Aquilas, N. A. (2014, November). Natural Resources Abundance and Economic Growth: The Cameroon Experience. Retrieved from https://www.researchgate.net/publication/305394943

34. Oyinlola, M. A., Adeniyi, O. A., \& Ibrahim D. Raheem. (2015). Natural resource abundance, institutions and economic growth in Africa. African Journal of Economic and Sustainable Development, IV(1).

35. Oyinlola, M., Adeniyi, O., \& Raheem, I. (2015). Natural resource abundance, institutions and economic growth in Africa'. African Journal of Economic and Sustainable Development, IV(I), 34-48.

36. Pesaran, M. H., \& Shin., Y. (1999). An Autoregressive Distributed-lag Modeling Approach to Co-integration Analysis. Econometric Society Monographs(31), 371-13.

37. Pesaran, M., Shin, Y., \& Smith., R. J. (2001). 'Bounds Testing Approaches to The Analysis of Level Relationship. Journal ofApplied Econometrics(16), 289-326.

38. Robinson, J. A., Ragnar T and Verdier T (2006), Political Foundations of the Resource Curse, Journal of Development Economics Vol.79, No.3, pp. 447-468.

39. Rohner, D. (2006), Beach Holiday in Bali or East Timor? Why Conflict Can Lead to Under- and Overexploitation of Natural Resources. Economics Letters 92: pp.113-17.

40. Ross, M. L. (1999). 'The Political Economy of the Resource Curse'. World Politics, 297-322.

41. Sachs, J. D., \& Warner, A. M. (1997). Natural resource abundance and economic growth. Harvard University Cambridge MA: Center for International Development and Harvard Institute for International Development .

42. Sachs, J., \& Warner, A. (1995). Natural Resource Abundance and Economic Growth. NBER Working Paper No. 5398.

43. Singh, Y. K. (2006). Environmental Science. New Age International (P) Ltd.

44. Smith, S. 1976. An Extension of the Vent-for-Surplus Model in Relation to Long-Run Structural Change in Nigeria.Oxford Economic Papers 28(3):426-446.

45. Southey, C. 1978. The Staples Thesis, Common Property and Homesteading. Canadian Journal of Economics 11(3):547-559.

46. Watkins, M.H. 1963. A Staple Theory of Economic Growth. The Canadian Journal of Economics and Political Science. 29(2):141-158.

47. Willebald, H., Badia-Miró, M., \& Pinilla, V. (2015). Natural Resources and Economic Development. Some Lessons From History. Working Paper. Retrieved from https://www.researchgate.net/publication/273382704

48. Wright, G. (2001). Resource-Based Growth Then and Now: Patterns of Integration in the Global Economy. Stanford University.

49. Wright, G., \& Jesse Czelusta. (2003). Mineral Resources and Economic Development, Sector Reform in Latin 
America . Stanford : Center for International Development.

50. Yimer, A. (2017). Macroeconomic, Political and Institutional Determinants of FDI inflows to Ethiopia: an ARDL approach' in A. Heshmati (ed.),Studies on Economic Development and Growth in Selected African Countries. Springer, 123-151.

51. Zagozina, M. (2014). The Resource Curse Paradox: natural resources and economic development in the former Soviet countries. University of Helsinki, Department of Forest Sciences. 